This is an electronic reprint of the original article. This reprint may differ from the original in pagination and typographic detail.

Author(s): Kuronen, Mikko; Zetterholm, Elisabeth

Title: $\quad$ Olika fonetiska drags relativa betydelse för upplevd inföddlikhet i svenska

Year: $\quad 2017$

Version:

Please cite the original version:

Kuronen, M., \& Zetterholm, E. (2017). Olika fonetiska drags relativa betydelse för upplevd inföddlikhet i svenska. Nordand, 12(2), 134-156.

https://doi.org/10.18261/issn.2535-3381-2017-02-03

All material supplied via JYX is protected by copyright and other intellectual property rights, and duplication or sale of all or part of any of the repository collections is not permitted, except that material may be duplicated by you for your research use or educational purposes in electronic or print form. You must obtain permission for any other use. Electronic or print copies may not be offered, whether for sale or otherwise to anyone who is not an authorised user. 


\title{
Olika fonetiska drags relativa betydelse för upplevd inföddlikhet i svenska
}

Mikko Kuronen

Jyväskylä universitet, Institutionen för språk- och kommunikationsstudier

E-post: mikko.j.kuronen@jyu.fi

\author{
Elisabeth Zetterholm \\ Stockholms universitet, Institutionen för språkdidaktik \\ E-post: elisabeth.zetterholm@isd.su.se
}

\section{SAMMANDRAG}

I den här undersökningen analyseras olika fonetiska drags betydelse för upplevd inföddlikhet i sverigesvenska som andraspråk. Lyssnarna $(\mathrm{n}=39)$ bedömde uttalets målspråklighet i imiterade talprov. Resultaten visar att de segmentella målspråksavvikelserna hade störst betydelse för upplevd inföddlikhet. Målspråksavvikelserna i yttrandeintonation, rytm och tonaccenterna påverkade inte lyssnarna i samma utsträckning som de segmentella bristerna. Prov med L2-intonation och målspråkliga segment fick lika bra bedömning - på gränsen mellan uppfattbar och icke-uppfattbar brytning - som prov med målspråklig intonation och målspråkliga segment. Om segmenten var målspråkliga, fick prov med L2-aktig rytm och målspråklig rymt en likvärdig bedömning. Sammantaget visar resultaten att (i) målspråkliga segmentkvaliteter är av central betydelse för ett mycket bra och/eller inföddlikt uttal och (ii) åtminstone i vårt empiriska upplägg med uppläst tal som material hade segmenten en starkare korrelation med upplevd inföddlikhet än prosodin. Eftersom segment tycks vara av stor betydelse för hur lyssnarna bedömer uttalet, ska de inte underskattas som inlärningsmål vid uttalsundervisningen.

Nyckelord: inföddlikhet; andraspråksuttal; perception; segment; prosodi.

\begin{abstract}
In this study we analyze the relative importance of different phonetic features for perceived native-likeness in L2 Swedish. The listeners $(n=39)$ evaluated the native-likeness of pronunciation in imitated speech samples with different deviations typical for L2 speakers. The results show that deviations in segment quality affected the listeners' perception most. Deviations in utterance intonation, rhythm and tone accents did not have the same effect as deviations in segments. Speech samples with L2 intonation and L1 segments were rated in the same way as speech samples with L1 intonation and L1 segments. If segments were L1 like, samples with L1 and L2 rhythm were rated in the same way. Over all, the results show that (i)
\end{abstract}


segments are of great importance for a really good and/or native-like pronunciation, and (ii) at least in our experimental setup with read-aloud speech, segments had a stronger correlation with perceived native-likeness than prosody. Because segments seem to be of great importance for how listeners evaluate pronunciation, they should not be underestimated as a learning goal in teaching of pronunciation.

Key words: native-likeness; L2 pronunciation; perception; segments; prosody

\section{Bakgrund och syftet med undersökningen}

Det finns många undersökningar om hur förstaspråkslyssnare (L1-lyssnare) upplever brutet uttal (uttal med en främmande accent). Med hjälp av lyssningstest har man kunnat fastställa att även fonetiskt otränade L1-lyssnare med en relativt stor säkerhet kan skilja mellan L1- och L2talare baserat på en kort talsekvens (Flege, 1984; Munro m. fl., 2003; Abrahamsson \& Hyltenstam, 2006; Kuronen, 2016a). Lyssningstest visar vidare att L1-lyssnarna ofta är rätt eniga i sin värdering av brytningsgraden (Leinonen, 2015; Kuronen, 2016a) och att de i vissa fall kan identifiera L2-talarnas förstaspråk. Den sistnämnda förmågan varierar dock avsevärt beroende på hur bekant brytningstypen är och hur stark brytningen är (Cunningham-Andersson \& Engstrand, 1989a; Boyd m.fl., 1999). Att främmande accent kan påverka L1-lyssnarnas uppfattning om L2-talaren - t.ex. uppfattningarna om talarens yrkeskompetens - har visats bl.a. av Boyd och Bredänge (2013).

När L2-uttal undersöks med hjälp av lyssningstest eller akustiskt liksom i de nämnda studierna ovan, är det ofta mycket svårt att säga något specifikt om de olika fonetiska dragens betydelse för hur uttalet upplevs eller bedöms av L1-lyssnarna. Detta beror på att lyssnarna också påverkas av sådana drag som inte har med de fonetiska aspekterna att göra, t.ex. talets grammatiska och lexikala innehåll och talarens röst (Derwing \& Munro, 2015). Därför kan man på grundval av lyssnarstudier ofta enbart konstatera att L2-talet gällande vissa fonetiska drag avviker från målspråket och att L1-lyssnarna noterar detta i en högre eller lägre grad. Vi vet vidare att antalet fonetiska målspråksavvikelser korrelerar positivt med upplevd grad av brytning (Cunningham-Andersson \& Engstrand, 1989a; Trofimovich \& Baker, 2006; Toivola, 2011) och att grövre avvikelser, t.ex. fonemiska fel (kategorifel), ger större utslag om brytning än lindrigare avvikelser. Sambandet mellan fonetisk brytning (eng. accentedness) och talets förståelighet (eng. intelligibility) är dock inte direkt, eftersom även L2-tal med en relativt stark brytning kan upplevas som lättförståeligt (Munro \& Derwing, 1995; Derwing \& Munro, 1997).

Man kan använda tre typer av talmaterial i lyssningstest: autentiskt tal, syntetiskt manipulerat tal eller imiterat tal. Test med autentiskt tal - speciellt spontant autentiskt tal - ger ofta den typ av fonetiskt svårtolkade resultat som beskrevs ovan. Syntetiskt manipulerat tal är mycket bra när analysen fokuserar på just fonetiska drags betydelse för lyssnarna och när analysen gäller enskilda ljud eller kortare prosodiska företeelser liksom ordintonation och stavelseduration (t.ex. O’Dell, 2003). Syntesen är dock svår att göra om analysen gäller längre och mer komplexa företeelser liksom yttrandeintonation, rytm och röstomfång, eftersom parametrarna då är många, överlappande och dessutom tenderar att samvariera med segmentella drag liksom vokalkvalitet. Den tredje materialtypen - imiterat tal - är mycket mindre använd i 
lyssningstest. Fördelen med imiterat tal är att olika uttalsdrag kan kombineras i olika konstellationer relativt enkelt, t.ex. olika prosodiska drag såsom yttrandeintonation, röstomfång och rytm med olika segmentella drag. En annan fördel är att talaren kan vara densamma i de olika talprov som ska bedömas av lyssnarna. Fördelarna bör vägas mot de nackdelar som imiterat tal har, nämligen att imitationerna kan vara mer eller mindre lyckade och att de kan göra ett konstgjort intryck hos lyssnaren.

I föreliggande studie används imiterat tal för att undersöka betydelsen av olika fonetiska brytningsdrag för målspråkslikt uttal av sverigesvenska. Fokus ligger på uttalets brytningsgrad - graden av främmande accent - inte talets förståelighet. Även om begripligt uttal kan anses vara det primära målet vid L2-inlärning, vill många L2-talare nå högre mål än så. Därför behövs också kunskap om hur specifika fonetiska drag påverkar upplevd grad av brytning/inföddlikhet i svenska. Sambanden mellan de fonetiska dragen och upplevd inföddlikhet undersöks här med hjälp av ett lyssningstest. Undersökningen går ut på att gradera sådana drag som är typiska för just finskspråkiga talares uttal av sverigesvenska, men en del av dragen, t.ex. tonaccenterna och yttrandeintonation, är också av intresse för L2-svenska generellt. Vi försöker besvara följande frågor:

(i) Hur viktiga är de prosodiska dragen (intonation och rytm = betoningsmönstret) $\mathrm{i}$ förhållande till segmenten för upplevd inföddlikhet?

(ii) Är rytmen i yttrandet viktigare än intonationen för upplevd inföddlikhet?

(iii) Hur stor betydelse har generell intonationskontur, tonaccenterna och röstomfång för upplevd inföddlikhet?

(iv) Är olika segmentgrupper olika viktiga för upplevd inföddlikhet?

Undersökningen har inspirerats metodologiskt av Una Cunningham-Andersson och Olle Engstrands undersökning (1989a, se äv.1989b), där forskarna gjorde ett lyssningstest med imiterat tal med en typisk finsk och brittisk brytning av sverigesvenska. Talaren i studien var Engstrand och undersökningen gick ut på att analysera vissa segments, segmentlängders och tonaccenternas betydelse för brytningsgraden. I föreliggande undersökning jämförs intonationens, rytmens (= betoningsmönstrets) och segmentens relativa betydelse för upplevd inföddlikhet. Vår förhoppning är att resultaten ger ny kunskap om finskspråkiga talares inlärning av sverigesvenskt uttal ur L1-lyssnarnas perspektiv. Kunskapen kan utnyttjas vid uttalsundervisning genom att undervisningen kan fokuseras på de perceptuellt väsentliga uttalsdragen (ifall sådana kan urskiljas). Till exempel inlärning av tonaccenterna och yttrandeintonationen har studerats akustiskt (t.ex. Kuronen, 2015; Kuronen m.fl., 2016; Kuronen \& Tergujeff, ms.), men dragens betydelse för L1-lyssnarna är underutforskad (om tonaccenterna se dock Abelin \& Thorén, 2015). Utöver språkparet svenska-finska har resultaten teoretiskt intresse för L2-perception generellt, eftersom de flesta tidigare studier om frågan har haft engelska som målspråk (Jesney, 2004). Imitationsmetoden i sig är sällsynt i tidigare forskning, och vi hoppas därför att undersökningen belyser för- och nackdelarna med metoden och bidrar till att utveckla den. Studien ingår i projektet Fokus på uttalsinlärningen med svenska som mål- och källspråk (www.jyu.fi/fokus), som finansieras av Svenska litteratursällskapet i Finland r.f. (SLS) 2015-2019. 


\section{Tidigare forskning om finskt uttal av L2-svenska och om hur L1-lyssnare upplever det}

Det finns relativt mycket kunskap om vilka drag i svenskt uttal som är svåra att lära sig för finskspråkiga talare. Sverigesvenska (mer precist mellansvenska) har varit målspråket i de flesta av studierna, medan inlärning av finlandssvenskt uttal är mycket mindre undersökt (för en översikt se Kautonen m.fl., 2016). Vad gäller segmenten i sverigesvenska kan finskspråkiga

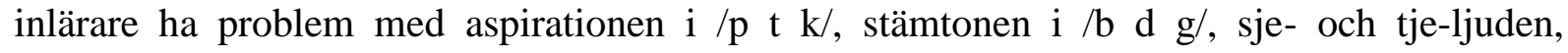
supradentalerna samt vissa långa vokaler, främst [u:], [a:], [e:] och [y:] (Kuronen, 2016b, se äv. Hyltenstam \& Magnusson, 1983; Bannert, 1984 och Zetterholm \& Tronnier, 2017). Bland de korta vokalerna är det bara [ $\Theta$ ] som tycks vålla nämnvärda problem; ljudet ersätts ofta med [u], [Y] eller [u] (Kuronen, 2016b). Typiskt för de långa vokalerna är att de inte är lika perifera som i L1-uttal, vilket leder till att den kvalitativa skillnaden mellan en lång och en kort allofon av ett vokalfonem uteblir och/eller är mindre än i L1-uttal (Kuronen, 2016b). Supradentalerna uttalas inte sällan som två separata ljud, speciellt [t] medför svårigheter. Vad gäller prosodin orsakar rytmen, yttrandeintonationen och tonaccenterna oftast problem för finskspråkiga inlärare (Bannert, 1984; Kuronen m.fl., 2016). Finsk L2-svenska präglas inte sällan av fallande yttrandeintonation och avsaknad av tonaccenter, medan den rytmiska målspråksavvikelsen består i att skillnaden mellan betonade och obetonade ord är för liten och rytmen mer stavelseän betoningsbaserad. Uttalet kan därför präglas av korta taltakter och tätt återkommande intonationstoppar, vilket är ett vanligt drag i andraspråksuttal oavsett mål- och källspråk (Rasier \& Hiligsmann, 2007). Ordbetoning tycks däremot behärskas rätt väl av finskspråkiga inlärare (Kautonen, 2016).

Medan typiska fonetiska målspråksavvikelser i finsk L2-svenska är relativt välkända, är kunskapen om deras betydelse för lyssnarnas upplevelse av uttalet mycket liten. De lyssnarstudier som gjorts har nästan uteslutande handlat om huruvida L1-lyssnarna känner igen finsk L2-svenska och hur de graderar den i förhållande till andra brytningar och L1-uttal. Resultaten visar att svenska lyssnare med stor säkerhet känner igen finsk brytning (80-100 \%, Cunningham-Andersson \& Engstrand, 1988a; Cunningham-Andersson \& Engstrand, 1989a; Boyd m.fl., 1999). Finsk brytning har lägre status än standarduttalet (Bijvoet, 1996), vilket torde gälla all brytning i förhållande till standarduttalet eller målspråket i dess olika regionala variationer (Dahlbäck, 1988; Torstensson, 2010). Det är dock svårt att säga något generellt om lyssnarnas attityder mot just finsk brytning, eftersom olika studier visar olika resultat (Loman, 1973; Dahlbäck, 1988). Detta beror troligen på olika talmaterial och metoder i olika studier och också på att attityder är svåra att mäta tillförlitligt och/eller jämförbart. Sannolikt varierar attityderna mot finsk brytning även regionalt: större erfarenhet av finsk brytning t.ex. i Norrbotten kan återspeglas i mer positiva attityder än i Sydsverige. Enligt Bijvoet (1996) tycks lyssnarna inte kunna skilja mellan finsk L2-svenska och finlandssvenska enbart baserat på uttalet (jfr samma iakttagelse i Cunningham-Andersson \& Engstrand, 1988b, s. 126: "FinlandSwedish was mistaken for a Finnish accent."). Det sistnämnda har många finlandssvenskar upplevt också personligen i Sverige (om frågan se bl.a. Reuter, 1974 och Wide, 2016).

Vad gäller de finskaktiga L2-dragens betydelse för lyssnarna är Cunningham-Andersson och Engstrand (1989a) oss veterligen den enda existerande undersökningen. I studien imiterades 14 olika drag typiska för finsk respektive brittisk L2-svenska. Dragen kombinerades i olika konstellationer till 35 uttalstyper. Tio av dragen var segmentella (bl.a. velariserat /1/, 
tremulerande $/ \mathrm{r} /$, oaspirerade klusiler och $/ \mathrm{r} /+$ dental av supradentalerna) och fyra prosodiska (endast accent 1, endast accent 2 och överdrivna kvantitetsdistinktioner). Resultaten visar att de mest signifikanta finskaktiga L2-dragen för lyssnarna $(\mathrm{n}=35)$ var velariserat /1/, tremulantiskt /r/, oaspirerade klusiler, överdrivna kvantitetsdistinktioner och sammanblandning av tonaccenterna. Förekomsten av dessa drag ensamt eller i kombination med något annat drag räckte till att minst $50 \%$ av lyssnarna ansåg att uttalet hade en främmande accent (foreign accent). Ju fler L2-drag uttalet behäftades med, desto enhetligare bedömde lyssnarna att uttalet var brutet. Ett ökat antal L2-drag av finsk respektive brittisk typ hade också en tydlig korrelation med bra identifiering av det imiterade L2-uttalet.

I föreliggande studie står yttrandeintonation och betoningsmönster (= rytm; förekomst och realisation av satsbetoning (= det mest framhävda ordet i yttrandet) samt förhållandet mellan denna satsbetoning och andra, mindre betonade stavelser i yttrandet) i fokus - drag som inte undersöktes av Cunningham-Andersson och Engstrand (1989a). Dessa drag kan antas konstituera eller åtminstone bidra till upplevd finsk brytning och mer generellt till uttal med en främmande accent. Undersökningen bör kunna ge ny kunskap om de prosodiska dragens perceptuella betydelse jämfört med segmenten.

\section{Talmaterialet, lyssnarna och testförfarandet}

I följande två avsnitt beskrivs talmaterialet i lyssningstestet och testets genomförande. De akustiska analyserna i avsnittet har gjorts med programmet Praat (Boersma \& Weenink, 2016).

\section{Talmaterialet}

Talaren i studien är artikelns förste författare som har finska som förstaspråk men som också behärskar väl sverigesvenskt uttal såsom det realiseras i Mellansverige (standarduttal, (öst)mellansvenska; Bruce, 2010; Riad, 2014). Eftersom studien fokuserar på typisk finsk L2svenska, förutsätter upplägget inte ett helt inföddlikt uttal av talaren. Det är dock viktigt att talaren kan imitera målspråket så pass bra att vissa av talproven uppfattas som närmast brytningsfria och kan användas som referenspunkter vid jämförelse av olika brytningstyper. Allra viktigast är att de olika fonetiska dragen kunnat hållas isär vid imitationerna så att talproven motsvarar den beskrivning som ges i tabell 1. Talaren har undervisat finskspråkiga språkstudenter i sverigesvenskt och finlandssvenskt uttal i många års tid och är van att använda båda varianter i sitt eget tal. Imitationerna övades under ett par veckors tid, och därefter gjordes provinspelningar som kommenterades av artikelns andra författare med sverigesvenska som sitt L1. De slutliga imitationerna spelades in i en tyst lokal med en digital ljudinspelare Roland RH09 kopplad till en bordsmikrofon av märket Sony ECM-959A. Inspelningarna sparades i WAV-format med en samplingsfrekvens på $44,1 \mathrm{kHz}$ (24 bitar).

Talproven består av en 21-24 sekunder lång sekvens där talaren berättar för sin bekant om en gemensam vän. Innehållet är identiskt i alla talprov och består av följande sex meningar:

Kalle åkte med buss till jobbet $i$ morse. Som du kanske vet var det kallt och jättehalt på morgonen. Bussen var sen och chauffören körde därför för fort. På Vasagatan kunde han inte bromsa $i$ tid utan körde på en lastbil. Kalle slog huvudet i sätet framför sig och togs in på sjukhus. Men jag hörde att han mår ganska bra redan. 
I tabell 1 visas de 13 brytningstyper som imiterats i lyssningstestet. De fonetiska hypoteser som ligger till grund för brytningstyperna baserar sig på tidigare undersökningar om finsk L2svenska.

Tabell 1. Fonetiska parametrar som varierats i de imiterade talproven. Beteckningarna L2-rytm och L2aktiga segment avser egenskaper som är typiska för finskspråkiga inlärares uttal av sverigesvenska.

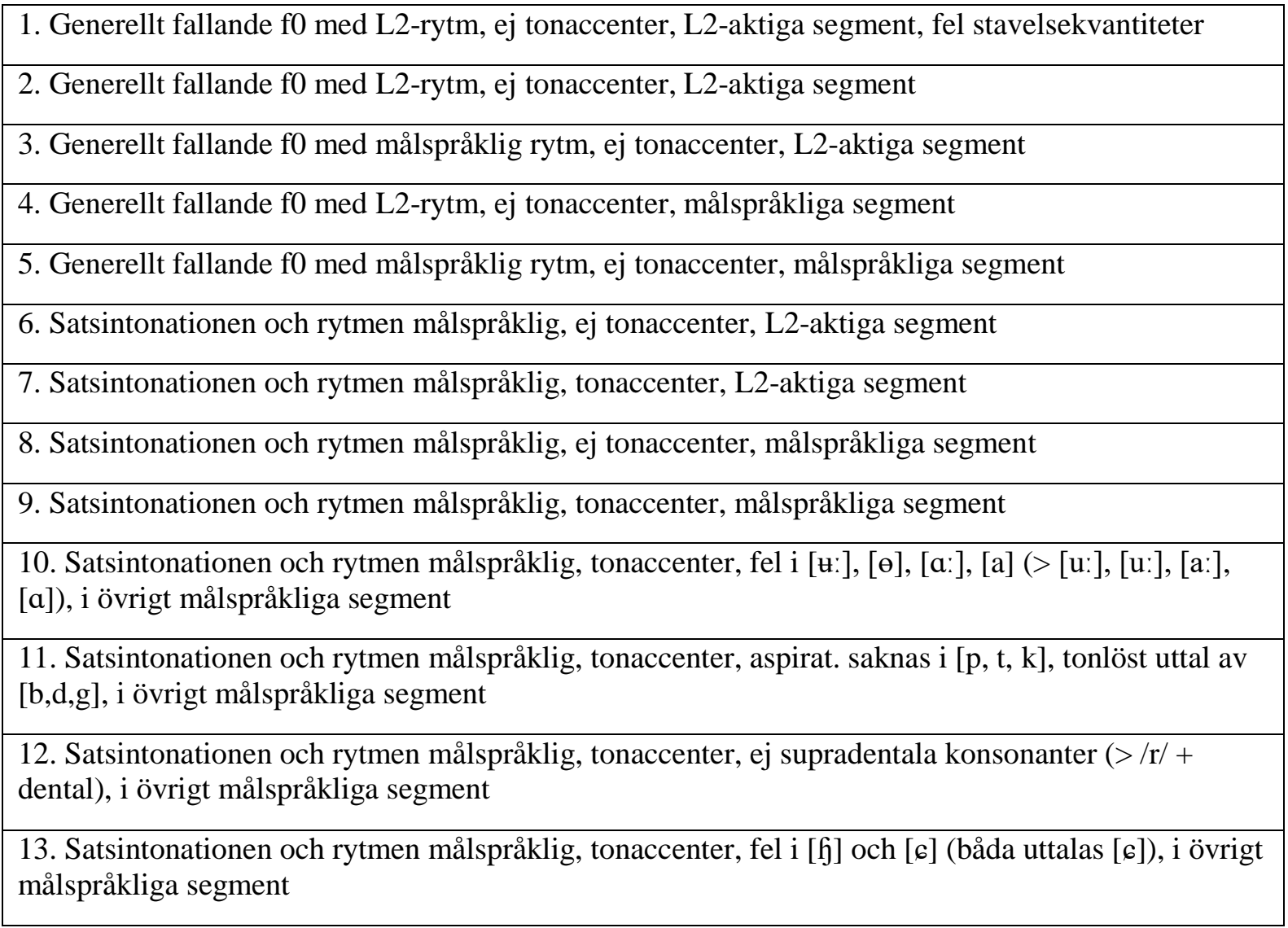

Talproven 1-5 syftar till att analysera vilken betydelse betoningsmönster (rytm) och segmentkvalitet har i ett uttal där intonationen är finskpåverkad (= uttal med en fallande yttrandeintonation (Iivonen, 2009) utan tonaccenter). Med en generellt fallande f0 (= grundtonsfrekvens) avses ett melodiförlopp där f0 är högst i början av yttrandet och de senare f0-topparna, även f0-toppen i yttrandets mest framhävda ord, är lägre än initialtoppen. Ett generellt f0-fall betyder således inte att f0 inte kan stiga lokalt efter initialtoppen (jfr bild 1a). I prov 1-5 är intonationen också i de betonade orden fallande (bild 1a). Fallande yttrande- och ordintonation har visats vara ett vanligt drag i finnars L2-svenska (bl.a. Kuronen, 2015 om ordintonationen). Prov 1 innehåller fyra felaktiga stavelsekvantiteter genom felaktig längdfördelning inom en stavelse: kallt > [ka:lt], halt > [halt], sen > [sen:], sjukhus > [Juk:hu:s]. Prov 1 är också det enda som innehåller prosodiska kategorifel (såvida tonaccentrealisationen med fallande intonation inte betraktas som kategorifel; denna kontur är ju realisationen i mellansvenska vid huvudbetoning (Bruce, 1977)).

Med L2-aktiga segment i talproven avses ett uttal som präglas av frånvaro av aspiration i $/ \mathrm{p} \mathrm{t} \mathrm{k/,} \mathrm{mindre} \mathrm{perifera} \mathrm{långa} \mathrm{vokaler,} \mathrm{bara} \mathrm{delvis} \mathrm{tonande} \mathrm{eller} \mathrm{tonlösa} \mathrm{/b} \mathrm{d} \mathrm{g/} \mathrm{och} \mathrm{frånvaro} \mathrm{av}$ supradentaler (uttalas som sekvens av $/ \mathrm{r} /+$ dental). Även $/ \mathrm{r} /$-ljuden är mer energiska och 
vokalkvaliteterna i obetonade stavelser mindre reducerade än i målspråkligt uttal. Dessa segmentella drag är typiska för finnars svenska, förekommer i varierande grad även på avancerad nivå (Kuronen, 2016b) och testas därför här. I proven 10-13 finns 4-6 segmentfel per prov, medan segmenten i övrigt är så målspråkliga som möjligt (= utan avsiktliga målspråksavvikelser).

Med målspråklig rytm i talproven 3 och 5 avses att det mest framhävda ordet (= det satsbetonade ordet) i yttrandet markeras starkare (med både en f0-topp och duration) än i proven 1, 2 och 4. Rytmen i talproven 3 och 5 är därmed mer betonings- än stavelsebaserad, skillnaden mellan det mest framhävda ordet och resten av yttrandet större samt taltakterna längre genom att vissa ord har blivit nedaccentuerade, dvs. har tappat sin lexikala betoning, vilket anses vara typiskt för mellansvenska (Leinonen m.fl., 1990; Bruce, 2010; Riad, 2014; se äv. bild 1a-d). Rytmen i finska - och i de imiterade talproven med L2-rytm i den här studien - är mer stavelseän betoningsbaserad, vilket innebär att (i) det mest framhävda ordet i yttrandet inte markeras med ökad duration i förhållande till de övriga, lexikalt (= fonologiskt) betoningsbara stavelserna, (ii) i princip alla ord i yttrandet bevarar sitt kvantitetsmönster såsom det realiseras vid lexikalt (= isolerat) uttal samt (iii) betoningsgrupperna därmed blir kortare och rytmen hackigare än i yttrandena med målspråklig rytm.

Yttrandeintonationen är inte generellt fallande i mellansvenska, även om intonationsfrasen ofta inleds med en s.k. initialitetsaccent (Myrberg, 2010). Dessa två melodiska egenskaper - initialitetsaccent och icke-fallande generell kontur - präglar yttrandena i talproven 6-13 (jfr bild 1b-d). Att den generella konturen inte är fallande beror på att mellansvenska markerar betoningen annorlunda än finska: betonad stavelse markeras med både duration och melodi (tonaccent). Tonaccenterna gör att senare meloditoppar i en intonationsfras inte sällan har lika hög eller högre f0 än initialitetsaccenten. Detta är vanligt speciellt när det betonade ordet ligger mot slutet av ett yttrande (s.k. rematisk betoning) och när ordet får satsbetoning (= uttalas med fokusaccent (Bruce, 1977) benämnd Prominence Level 2 av Myrberg, 2010). Att yttrandekonturen i mellansvenska formas av baslinjen, betoningens placering i yttrandet och tonaccenterna ligger i linje med den s.k. superpositionella intonationsteorin (superpositional representation of intonation, Fujisaki, 1988). De olikheter i intonation som finns mellan uttalen i bild 1a och bild 1d brukar beskrivas som viktiga tonala inlärningsmål för finskspråkiga talare av sverigesvenska (Kuronen \& Leinonen, 2010), men deras betydelse för L1-lyssnarna har inte undersökts tidigare.

Yttrandena i talproven 6-13 har större standardavvikelse (SD), högre genomsnittlig lutning (mean absolute slope) och högre genomsnittlig f0 än yttrandena i proven 1-5, vilket beror på skillnaderna i generell kontur och/eller på tonaccenterna (tabell 2). Uttal med tonaccenter avser i talproven ett uttal där ett fokuserat ord med accent 1 realiseras med melodiförloppet $\mathrm{L}^{*} \mathrm{H}$ (= låg ton + hög ton $\mathrm{i}$ den accentuerade stavelsen; bild 1d) och ett fokuserat ord med accent 2 med melodiförloppet $\mathrm{H}^{*} \mathrm{LH}$ (= första höga tonen + låg ton i ordets huvudbetonade stavelse; bild 2a). I talprov utan tonaccenter uttalas fokuserade ord med ett f0fall som börjar i den betonade stavelsen ( $H^{*} \mathrm{~L}(\mathrm{~L})$; bild $\left.2 \mathrm{~b}\right)$. Proven 6-7 har målspråklig intonation och rytm, men avviker från målspråket antingen vad gäller tonaccentrealisationen och/eller segmentkvaliteten. Proven 8-9 syftar till att testa tonaccenternas betydelse för upplevd inföddlikhet, medan proven 10-13 testar olika segmentgruppers relativa perceptuella betydelse (bild 3). 
Talprov 1 bör upplevas som mest avvikande från målspråket p.g.a. fonologiska fel (= fel i stavelsekvantiteter), medan prov 9 bör upplevas som mest målspråkligt. Lyssnarnas bedömning av proven 8 och 9 blir intressant, eftersom proven enbart skiljs åt av tonaccenterna. Likaså är bedömningen av proven 2, 3, 6 och 7 intressant: hypotesen är att målspråkligheten ökar från prov 2 via 3 och 6 till 7, eftersom prosodin är mest målspråklig i prov 7. Man antar normalt att prosodi är viktigare för målspråkligt uttal än segment (Bannert, 2004; Hahn, 2004; Bruce, 2012), vilket skulle innebära att proven 1-5 bedöms avvika mer från målspråket än proven 6-13.

I bilderna 1-3 exemplifieras ett antal centrala drag vid imitationerna: yttrandeintonation, tonaccenter och segmentkvaliteter (jfr transkriptionerna). I tabell 2 anges genomsnittlig f0, genomsnittlig lutning och standardavvikelse i talproven. I proven 1-5 är dessa värden lägre/mindre än i proven 6-13 på grund av skillnaderna i yttrandeintonationen och/eller tonaccenterna. Lägre genomsnittlig f0 och mindre röstomfång har visats vara typiska för finsk L2-svenska och även för L1-finska jämfört med sverigesvenska (Kuronen, 2015; Kuronen \& Tergujeff, ms.).

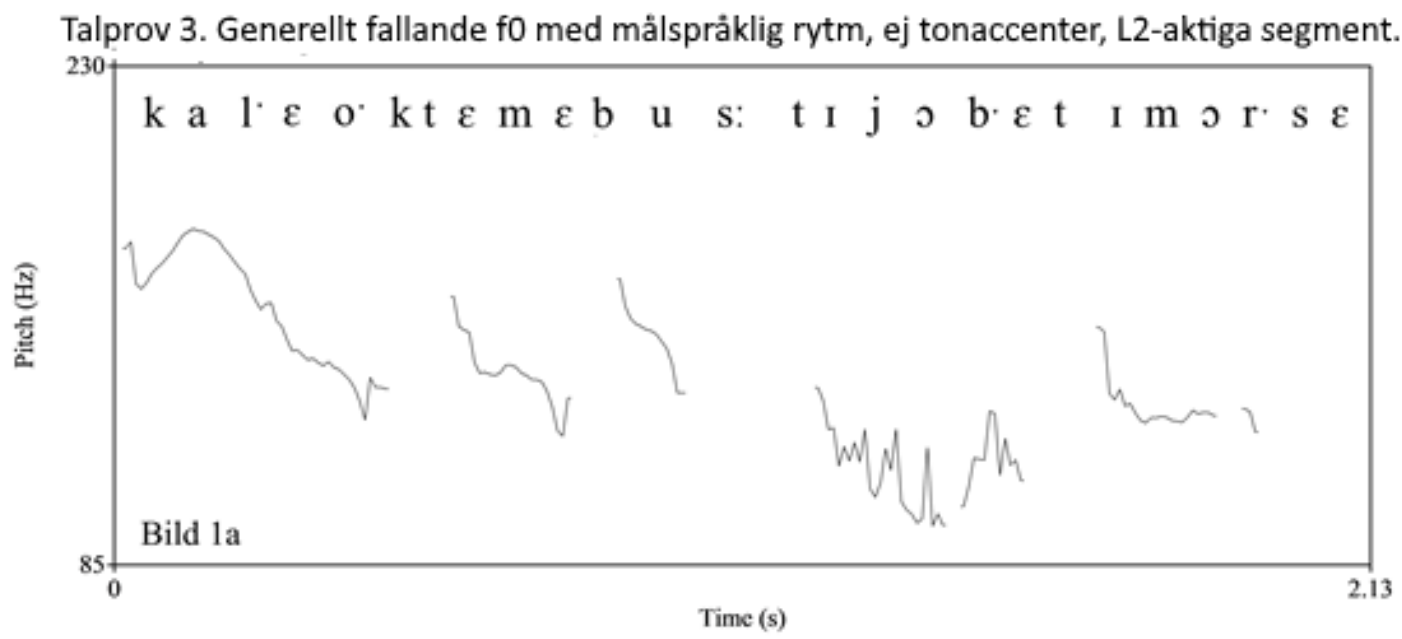

Talprov 6. Satsintonationen och rytmen målspråklig, ej tonaccenter, L2-aktiga segment.

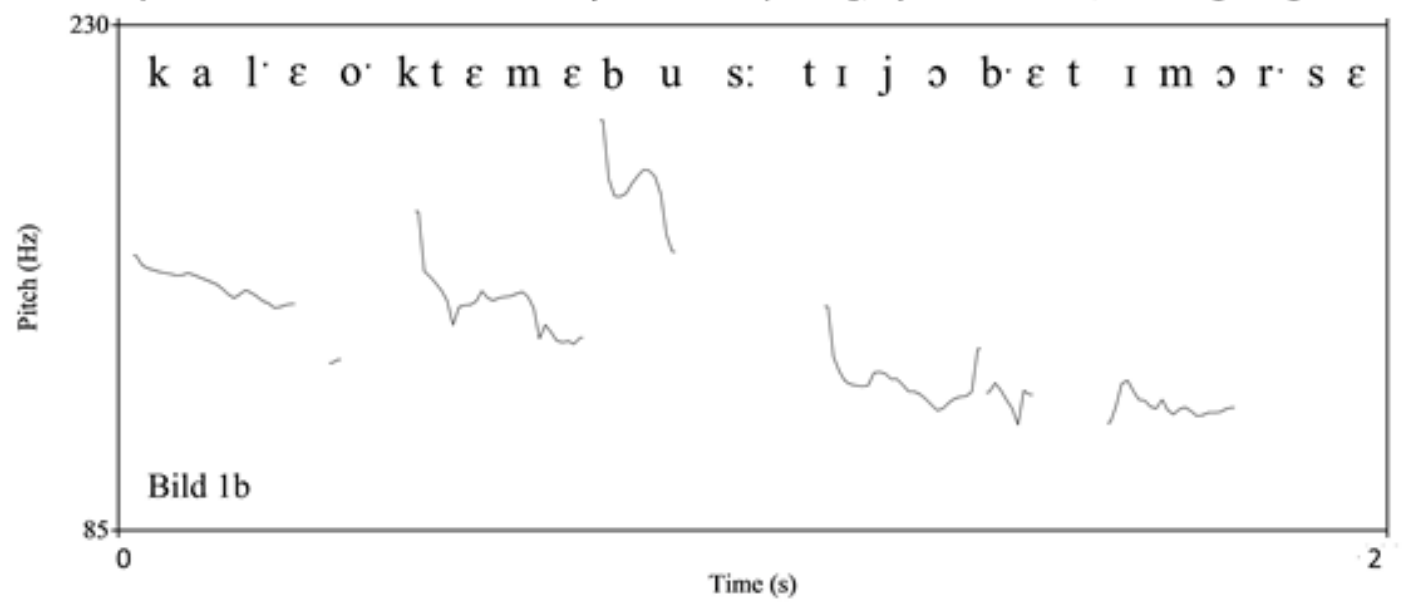



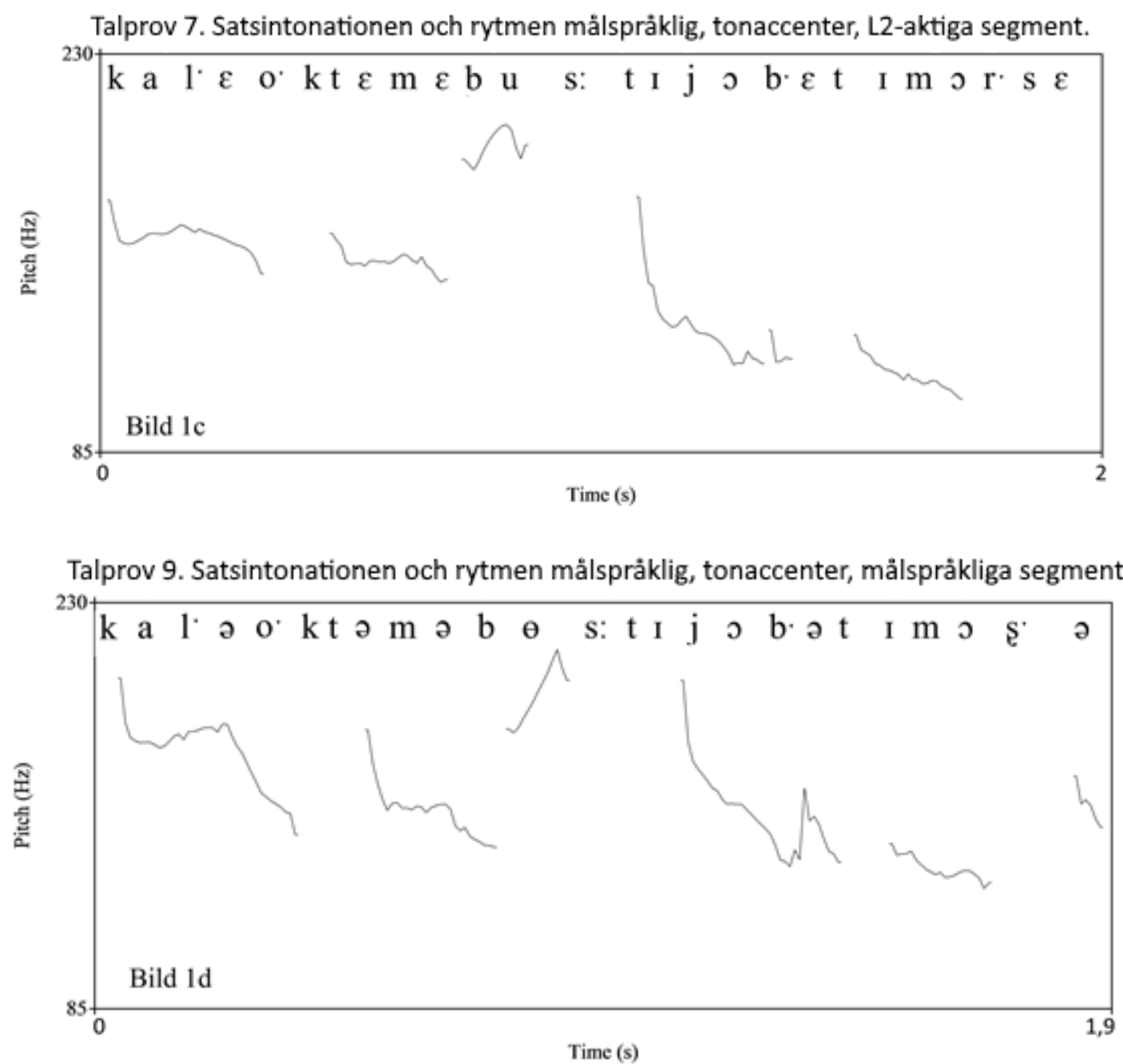

Bild 1a-d. Analyserna exemplifierar yttrandeintonation, tonaccenter och segmentkvaliteter (jfr transkriptionerna) i proven 3, 6, 7 och 9. I bild 1a (prov 3) avviker uttalet från målspråket genom fallande yttrandeintonation, frånvaro av tonaccenterna (i bild 1a accent 1: $\mathrm{H}^{*} \mathrm{~L}-$ kontur i satsbetonat buss) och segmentkvaliteter (bl.a. avsaknad av supradental i morse). Uttalet i bild 1d är målspråkligt tack vare initialitetsaccent, nedaccentuering av obetonade stavelser, tonaccent i satsbetonad stavelse ( $\mathrm{L} * \mathrm{H}-$ kontur i buss) och målspråkliga segmentkvaliteter (bl.a. i busss och morse). 

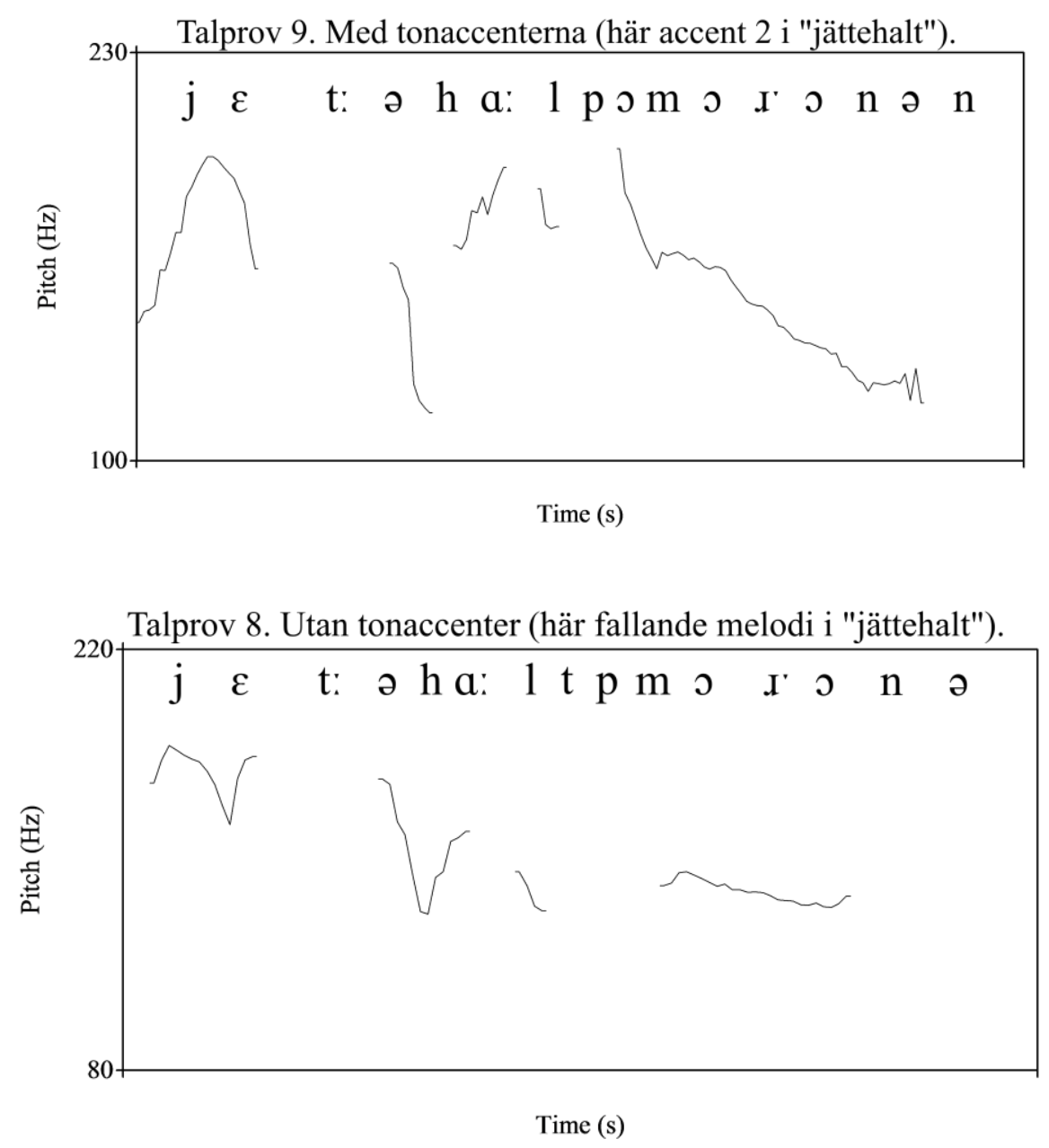

Bild 2a-b (2a högst upp). Förekomst respektive avsaknad av tonaccenterna exemplifierat genom sekvensen jättehalt på morgonen i prov 9 (H*LH-kontur i satsbetonat jättehalt) och i prov 8 (H*LLkontur i satsbetonat jättehalt). 


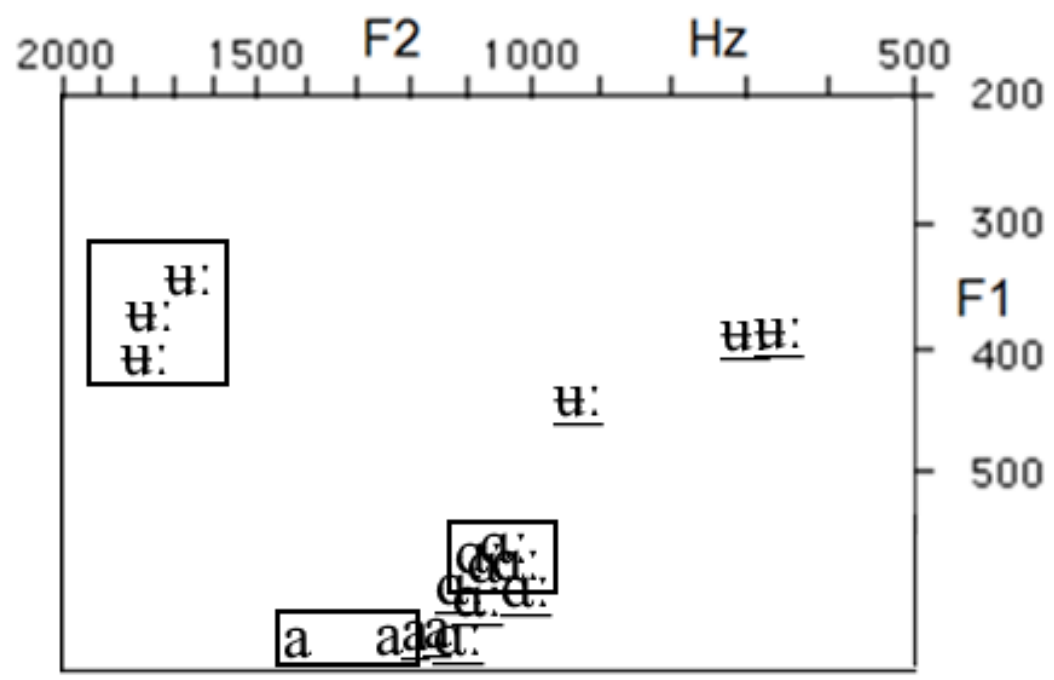

Bild 3. Frekvenserna för formant 1 (f1) och formant 2 (f2) i [u:], [a:] och [a] i proven 9 och 10. Vokalerna i prov 9 (målspråkligt uttal) står innanför rektanglarna, medan vokalerna i prov 10 (finskaktigt uttal) anges med understrykning. Tydligast är skillnaden mellan [H:] som i prov 10 har målspråklig, hög f2 och i prov 10 låg f2. I prov 9 görs en målspråklig skillnad på c. 1 bark mellan [a] och [a:], medan både kort och lång allofon uttalas med finskaktig kvalitet i prov 10 (ljudet intar ett mellanläge mellan [a] och [a:]).

Tabell 2. Genomsnittlig f0 i Hz, genomsnittlig lutning (mean absolute slope) i Hz/sekund och standardavvikelse (SD) av f0 i Hz i talproven. I prov med målspråksavvikande intonation (1-5) är värdena genomsnittligt lägre/mindre än i prov med målspråklig intonation (prov 6-13). Genomsnittsvärdena för dessa två talprovsgrupper anges på de två sista raderna.

\begin{tabular}{|l|l|l|l|}
\hline Talprov & \multicolumn{1}{|c|}{ Genomsn. f0 } & \multicolumn{1}{|c|}{ Lutning } & Standardavvik. \\
\hline 1 & 155 & 195 & 22 \\
\hline 2 & 135 & 166 & 21 \\
\hline 3 & 146 & 200 & 24 \\
\hline 4 & 147 & 181 & 26 \\
\hline 5 & 145 & 262 & 33 \\
\hline 6 & 148 & 228 & 24 \\
\hline 7 & 158 & 228 & 25 \\
\hline 8 & 151 & 288 & 37 \\
\hline 9 & 161 & 310 & 34 \\
\hline 10 & 159 & 212 & 26 \\
\hline 11 & 153 & 256 & 40 \\
\hline 12 & 163 & 331 & 36 \\
\hline 13 & 158 & 334 & 43 \\
\hline
\end{tabular}




\begin{tabular}{|l|l|l|l|}
\hline Proven 1-5 & 146 & 201 & 25 \\
\hline Proven 6-13 & 156 & 273 & 33 \\
\hline
\end{tabular}

\section{Lyssningstestet}

Talproven spelades upp för 39 lyssnare. 30 av lyssnarna hade svenska som L1, medan 9 lyssnare talade svenska som andraspråk med förstaspråken kinesiska, tyska, grekiska, rumänska, engelska, gujarati, kurdiska, spanska respektive amhariska. L2-lyssnarna hade mycket goda färdigheter i och lång erfarenhet av svenska. De två grupperna behandlas separat i analysen. L1-lyssnarna sade sig tala någon av följande varianter/dialekter: stockholmska (17 st.), norrländska (3), dalmål (2), mellansvenska (1) och skånska (1). Två lyssnare uppgav att de inte talar någon speciell dialekt, medan fyra lyssnare inte har svarat på frågan. Bortsett från en person hade L1-lyssnarna inte haft någon nära kontakt med finska.

Lyssnandet skedde i klassrum med bra högtalarsystem. Lyssnarna fick ett formulär där de ombads att värdera på skalan 1-6 varje talprovs målspråklighet vad gäller uttalet. En sexgradig skala användes för att en sådan visat sig tillräckligt noggrann för att kunna skilja olika prov/talare åt medan den samtidigt är tydlig att använda för lyssnarna (för en översikt om olika skalor se Jesney, 2004). En skala med fler än sex steg - t.ex. nio steg - skulle visserligen ha kunnat lyfta fram ännu mer subtila skillnader mellan talproven, men beskrivningen av de olika stegen på en sådan skala är svårare. Beskrivningen är dock viktig för att den bidrar till att lyssnarna interindividuellt använder skalan så likt som möjligt. För att underlätta bedömningen fick lyssnarna i den här studien följande beskrivning av skalan (beskrivningen fanns också i svarsformuläret ovanför den numeriska skalan för varje talprov):

$$
\begin{aligned}
& 1=\text { mycket dåligt uttal, mycket kraftig brytning } \\
& 2=\text { dåligt uttal, kraftig brytning } \\
& 3=\text { uttalet skapligt, dock tydlig brytning } \\
& 4=\text { bra uttal, även om brytning hörs } \\
& 5=\text { mycket bra uttal, nästan ingen brytning } \\
& 6=\text { inföddlikt }
\end{aligned}
$$

Lyssnarna fick se den inspelade texten före testet, bl.a. för att de skulle förstå att varken grammatik eller ordval skiljer talproven åt och att det i proven inte finns några grammatiska eller lexikala L2-drag. Före testet fick lyssnarna veta att det är samma manliga talare som uttalar samma röstmeddelande på många olika sätt och att lyssnarnas uppgift enbart består i att värdera uttalets målspråklighet. Ingenting annat sades om talaren. Testförfarandet övades med två talprov, men bedömningen av dessa prov har inte beaktats i analysen. Två prov spelades upp två gånger som kontrollprov för att värdera reliabiliteten av lyssnarnas bedömningar. Eftersom uppgiften kunde antas vara svår för lyssnarna, hölls en paus på ca 20 sekunder efter varje prov. Detta gav lyssnarna en möjlighet att nollställa sig inför varje nytt prov, vilket antogs bidra till att de orkade fokusera på uppgiften under hela testet som med anvisningarna tog ca 15 minuter. Testet gjordes i två lyssnargrupper med två motsatta provordningar: från prov 1 till 15 och från prov 15 till 1 (13 talprov +2 kontrollprov $=15$ prov $)$. Provordningen var sådan att de olika 
fonetiska dragen och prov som förväntades få olika brytningsindex blandades. Den andra lyssnargruppen blev mindre än den förstnämnda (sex lyssnare). Grupperna har emellertid bedömt talproven på ett mycket likartat sätt, vilket tyder på att provordningen inte påverkat lyssnarbedömningarna (jfr resultatdelen). Också bedömningen av kontrollproven bland L1lyssnarna stöder denna slutsats (jfr resultatdelen). Det hade varit idealiskt att ha slumpmässig ordning av talproven för varje lyssnare, men det var inte möjligt p.g.a. att testet gjordes $\mathrm{i}$ klassrum. I ett nätbaserat test kunde slumpmässig ordning ha använts, men informantrekryteringen och speciellt kontroll av testförfarandet är ofta svårt i nättest. I den typ av test som vår analys gäller är noggranna anvisningar och kontroll av testförfarandet av stor betydelse. Resultaten har analyserats med två statistiska tester: parade t-tester (Paired Samples T test) och med icke-parametriska Wilcoxons rangsummetester (Wilcoxon Signed Ranks Test). Testerna gav närmast identiska p-värden, och därför ges nedan bara resultaten av de parade ttesterna. Lyssnarna fick också kommentera uttalet i varje talprov genom en öppen, valfri kommentar i svarsformuläret. Kommentarerna behandlas i analysen.

\section{Resultat}

Bedömningen av talproven behandlas i de två följande avsnitten. Därefter behandlas lyssnarnas kommentarer om talproven.

\section{L1-lyssnarnas bedömning av talproven}

L1-lyssnarnas bedömning av talproven sammanfattas i tabell 3. Reliabiliteten av bedömningarna kan anses vara god: 17 av 30 lyssnare har gett de två kontrollproven samma bedömning två gånger, 8 lyssnare har gett samma bedömning för det ena av kontrollproven, och hos ingen lyssnare skiljer sig kontrollproven åt med mer än ett steg på skalan. Lyssnarna har också bedömt talproven sinsemellan likartat: proven 4, 5, 8 och 9 har fått enbart bedömningar 5 eller 6 , och de prov som fått lägst index har fått inga eller endast en enstaka bedömning 5 eller 6. Genomsnittet för samtliga prov är 4,39. Lyssnarna har använt hela skalan, även om bedömningarna 1 är ytterst få (3 av tot. 390). Bedömningen 2 har getts 19 gånger. Lyssnarens egen dialekt tycks ha påverkat bedömningen i viss mån, även om antalet lyssnare per grupp bortsett från den stockholmska gruppen är litet och iakttagelsen därför vilar på osäker grund. Lyssnarna med stockholmsdialekt har dock ett genomsnitt på 4,48, lyssnarna med dalmål 4,19 och lyssnarna med norrländska 4,02. Den skånska lyssnarens genomsnitt är högst $(4,92)$, vilket kan bero på att hon p.g.a. sin dialekt inte kunnat skilja proven åt lika väl som de övriga lyssnarna och bedömt dem mer generöst.

Tabell 3. L1-lyssnarnas bedömning av talproven. I kolumnerna anges talprovet, genomsnittlig bedömning av talprovet ( $0-6)$, standardavvikelse (SD), variationsvidd (27/30 bedömningar; de tre mest avvikande bedömningarna har inte beaktats) samt antalet bedömningar inföddlikt (6).

\section{TALPROV}

GENOMSN.

SD

VAR. (90 \%)

ANTAL 6 


\begin{tabular}{|c|c|c|c|c|}
\hline $\begin{array}{l}\text { 1. Gen. f0-fall, L2-rytm, ej tonacc., } \\
\text { L2-segm., fel stav.längder }\end{array}$ & 3,40 & 0,96 & $2-4$ & 2 \\
\hline $\begin{array}{l}\text { 2. Gen. f0-fall, L2-rytm, ej tonacc., } \\
\text { L2-segm. }\end{array}$ & 3,30 & 1,02 & $1-5$ & 0 \\
\hline $\begin{array}{l}\text { 3. Gen. f0-fall, målspråklig rytm, ej } \\
\text { tonacc., L2-segm. }\end{array}$ & 3,30 & 0,91 & $2-4$ & 1 \\
\hline $\begin{array}{l}\text { 4. Gen. f0-fall, L2-rytm, ej tonacc., } \\
\text { målspr. segm. }\end{array}$ & 5,60 & 0,49 & $5-6$ & 18 \\
\hline $\begin{array}{l}\text { 5. Gen. f0-fall, målspråklig rytm, ej } \\
\text { tonacc., målspr. segm. }\end{array}$ & 5,63 & 0,49 & $5-6$ & 19 \\
\hline $\begin{array}{l}\text { 6. Satsint. och rytmen målspr., ej } \\
\text { tonacc., L2-aktiga segm. }\end{array}$ & 3,26 & 0,90 & $2-4$ & 0 \\
\hline $\begin{array}{l}\text { 7. Satsint. och rytmen målspr., } \\
\text { tonacc., L2-aktiga segm. }\end{array}$ & 3,66 & 0,84 & $3-5$ & 0 \\
\hline $\begin{array}{l}\text { 8. Satsint. och rytmen målspr., ej } \\
\text { tonacc., målspråkliga segm. }\end{array}$ & 5,46 & 0,50 & $5-6$ & 14 \\
\hline $\begin{array}{l}\text { 9. Satsint. och rytmen målspr., } \\
\text { tonacc., målspråkliga segm. }\end{array}$ & 5,40 & 0,49 & $5-6$ & 12 \\
\hline $\begin{array}{l}\text { 10. Satsint. och rytmen målspr., } \\
\text { ton., fel i }[\mathrm{u}:],[\Theta],[a:],[a]\end{array}$ & 4,20 & 0,55 & $3-5$ & 0 \\
\hline $\begin{array}{l}\text { 11. Satsint. och rytmen målspr., } \\
\text { tonacc., oasp. }[\mathrm{p}, \mathrm{t}, \mathrm{k}] \text {, tonl. }[\mathrm{b}, \mathrm{d}, \mathrm{g}]\end{array}$ & 3,93 & 0,78 & $3-5$ & 0 \\
\hline $\begin{array}{l}\text { 12. Satsint. och rytmen målspr., } \\
\text { tonacc., ej supradent. }\end{array}$ & 4,53 & 0,62 & $4-5$ & 2 \\
\hline $\begin{array}{l}\text { 13. Satsint. och rytmen målspr., } \\
\text { tonacc., }[\hat{6}] \text { och }[6]>[6]\end{array}$ & 5,43 & 0,72 & $4-6$ & 16 \\
\hline
\end{tabular}

25 lyssnare har gett något eller några av talproven bedömningen 6 , medan fem lyssnare inte har gett 6 för något prov (däremot 5 för flera prov). De lyssnare som gett bedömningen 6 har gjort det i genomsnitt 3,3 gånger. Vanligast är att lyssnaren har gett 6 för två eller tre av proven 4, 5, 8, 9 och 13. Ett tydligt mönster är att prov med målspråkliga segment har fått höga index, medan prov med målspråksavvikelser i segment har fătt lägre index: ju fler/större målspråksavvikelser i segmenten, desto lägre index oavsett prosodin (figurerna 1 och 2). Genomsnittsindexet för alla prov med målspråkliga segment varierar mellan 5,40 och 5,63, dvs. mellan nästan ingen brytning (5) och inföddlikt (6). Dessa prov kan tolkas befinna sig på gränsen mellan uppfattbar 
och icke-uppfattbar brytning (jfr Abrahamsson \& Hyltenstam, 2004; Abrahamsson, 2009; Kuronen, 2016a). Det är anmärkningsvärt att varken målspråklig yttrandeintonation eller rytm har påverkat bedömningen ifall segmenten varit målspråkliga: prov 4 har fått en likvärdig bedömning som prov 5, och dessa två prov med prosodiska L2-drag har t.o.m. högre index än proven 8 och 9. Skillnaden mellan prov 5 och prov 9 är signifikant på nivån $p<0.050(p=0,032)$, men skillnaden mellan prov 4 och prov 9 är inte signifikant $(\mathrm{p}=0,083)$. Proven 8 och 9 har fått ett likvärdigt index trots att prov 8 saknar tonaccenterna (= fokuserade ord uttalas med $\mathrm{H}^{*} \mathrm{~L}(\mathrm{~L})$ kontur). Skillnaden mellan prov 8 och prov 9 är inte signifikant $(\mathrm{p}=0,573)$.

Varken generellt fallande yttrandeintonation eller L2-aktig rytm har således påverkat lyssnarbedömningarna negativt om segmenten har varit målspråkliga. Vid bedömningen av prov med icke-målspråkliga segment har målspråklig yttrandeintonation, rytm och tonaccenterna dock en positiv effekt: prov 7 har fått högre index än proven 2, 3 och 6 . Skillnaden mellan prov 7 och prov 3 är signifikant $(\mathrm{p}=0,014)$. Proven $10-13$ med målspråksprosodi men med vissa brister i segmenten har fått klart högre index än prov med målspråksprosodi men med L2-aktiga segment, vilket är förväntat. Bland de undersökta segmentgrupperna har klusilfel störst betydelse för lyssnarna: skillnaden mellan prov 11 (klusilfel) respektive prov 10 (vokalfel) och prov 12 (supradentalfel) är tydlig. Skillnaden mellan prov 11 och prov 12 är signifikant $(\mathrm{p}=0,000)$, likaså skillnaden mellan prov 11 och prov $10(\mathrm{p}=0,018)$. Att uttalet av supradentalerna som $/ \mathrm{r} /+$ dental har påverkat indexet klart mindre än klusilfelen är något överraskande. Sammanblandning av sje- och tje-ljuden (prov 13; båda ljud uttalades med tje) har påverkat bedömningarna klart mindre än fel i de övriga segmentgrupperna, vilket är förväntat med tanke på att den fonetiska skillnaden mellan sje och tje varierar talarvis i mellansvenska och målspråksavvikelsen i detta prov därför inte var speciellt hörbar. Därtill ansågs prov 13 påminna om norrländska av en del lyssnare (se avsnittet om lyssnarkommentarerna). Skillnaden mellan prov 13 och prov 5 (med högst index) är inte signifikant $(\mathrm{p}=0,136)$.

Sammantaget visar analysen av L1-lyssnarnas bedömningar (tabell 3, figur 2) att (i) målspråkliga segment har en stark positiv korrelation med upplevd inföddlikhet, (ii) intonationen och rytmen påverkar inte alls inföddlikheten i lika hög grad som segmenten, (iii) i prov med L2-segment förbättrar målspråklig intonation och rytm upplevd inföddlikhet, men endast till en viss del samt (iv) bland segmenten har klusilfelen störst negativ inverkan på upplevd inföddlikhet följda av vokalerna, supradentalerna samt sje- och tje-ljuden i fallande ordning.

Att segmentfel gett större utslag än prosodi kan bero på att lyssnarna betraktat talproven som uppläst tal. Det kan leda till att lyssnarna accepterat sådana tonala och rytmiska drag som kunde påverka deras bedömning av spontant tal negativt. Bortsett från prov 1 hade alla prov rätt stavelsekvantiteter och också rätt betonad stavelse i betonade ord, vilket gör att proven var lätta att förstå; detta kommenterades också av lyssnarna. Det kan ha bidragit till att lyssnarna haft större tolerans mot prosodiska än mot segmentella målspråksavvikelser. De prosodiska felen kan antas bli uppenbara först när de påverkar förståeligheten, medan avvikelserna i segment är tydligare till sin karaktär: ett felaktigt eller ett avvikande segment är lättare att notera och kategorisera som fel eller avvikelse än en målspråksavvikelse t.ex. i yttrandeintonationen. Resonemanget får stöd av att prov 1 med fyra felaktiga stavelsekvantiteter fick ett likvärdigt index som proven 2 och 3, vilka inte innehöll kategorifel. Det är inte heller uteslutet att 
lyssnarna betraktat talaren i vissa prov som finlandssvensk, därför betraktat dessa prov som finlandssvenska, och därmed tolererat en annorlunda prosodi i dem. Det förklarar dock inte varför de gett just prov med L2-segment så låga bedömningar: toleransen mot det finlandssvenska borde i så fall också ha gällt prov med finska/finlandssvenska segmentkvaliteter. Att prov 8 har fătt samma index som prov 9 kan likaledes bero på tolerans mot prosodisk variation: avsaknaden av $\mathrm{H}^{*} \mathrm{LH}-\mathrm{kontur}$ vid fokusbetoning i prov 8 kunde ju tänkas bero på talarens dialekt, även om lyssnarna tycktes betrakta de mest målspråkliga proven som just mellansvenska (se avsnittet om lyssnarkommentarerna). Ett mindre energiskt eller ett mindre engagerat uttal kan också leda till att tonaccent 2 realiseras som H*LL (= konturen vid huvudbetoning benämnd Prominence Level 1 av Myrberg, 2010), vilket kan förklara att prov 8 fått samma index som prov 9.

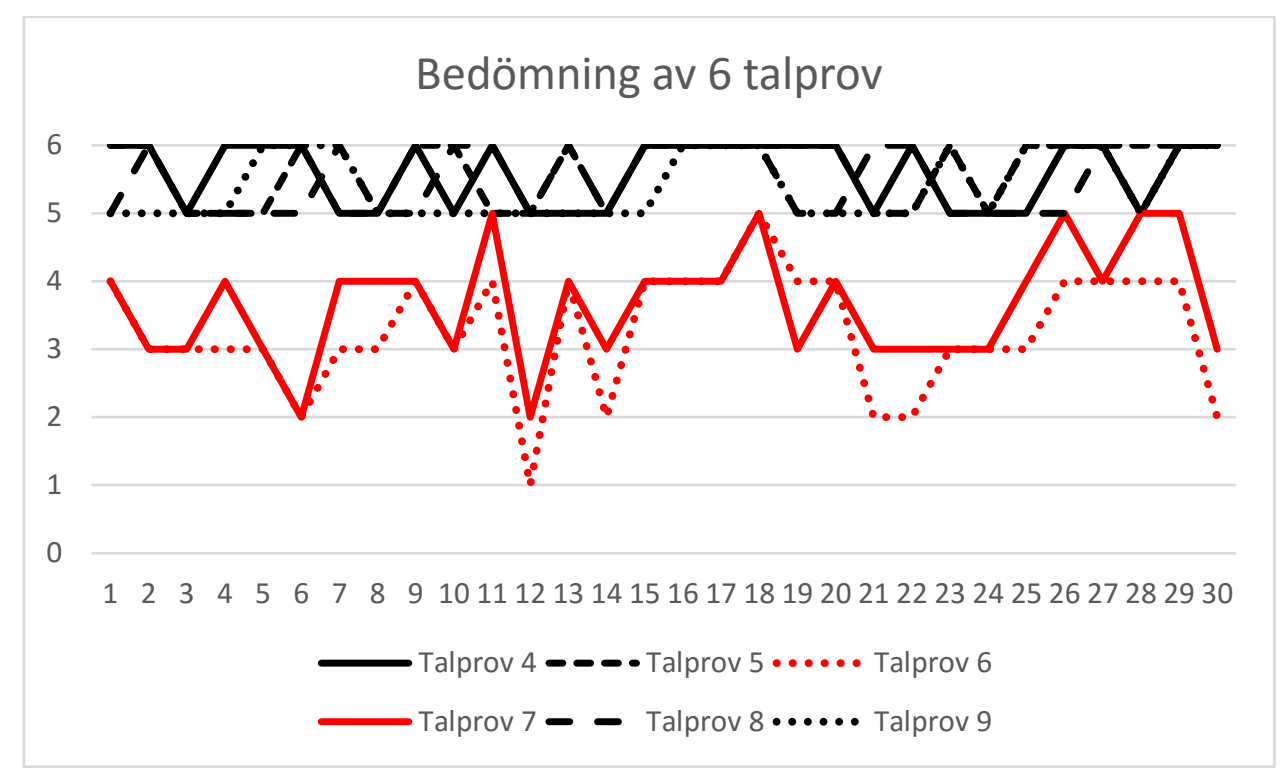

Figur 1. Bedömningen av talproven 4, 5, 6, 7, 8 och 9. Lyssnarna $(\mathrm{n}=30)$ anges horisontellt, bedömningarna vertikalt (0-6). Prov med målspråkliga segment (4, 5,8 och 9) har fått enbart bedömningar 5 och 6 trots att yttrandeintonationen, rytmen och/eller tonaccentrealisationen inte varit målspråkliga i proven 4, 5 och 8. Proven 6 och 7 med L2-aktiga segment har fått klart lägre index. Figuren visar också att lyssnarna varit olika stränga i sin bedömning, vilket syns i att kurvorna för proven 6 och 7 (lägst i figuren) liknar varandra till formen. 


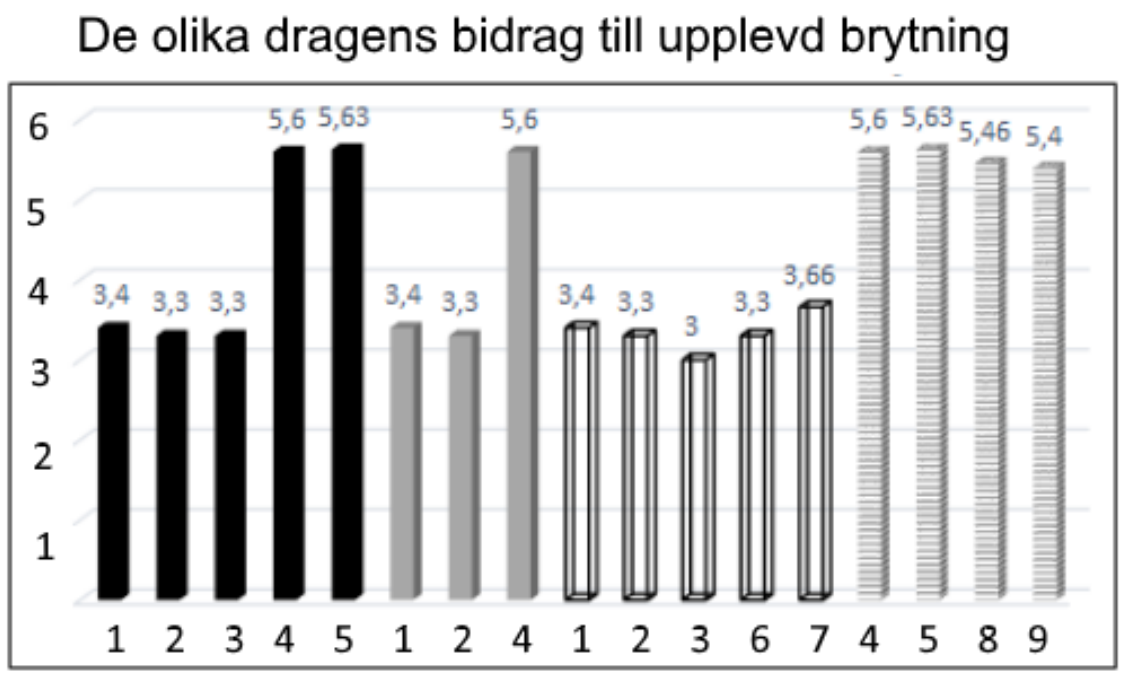

Figur 2. De olika fonetiska dragens relativa bidrag till upplevd brytningsgrad. Talproven anges horisontellt, bedömningen av dem vertikalt (0-6). I prov med mörk stapel är yttrandeintonationen målspråksavvikande (proven 1-5). I prov med grå stapel är rytmen målspråksavvikande (1, 2 och 4). I prov med vit stapel är segmenten målspråksavvikande, medan de streckade staplarna anger prov med målspråkliga segment men med varierande prosodiska drag. Målspråkliga segment är den fonetiska komponent som haft störst betydelse för lyssnarnas bedömning av uttalets målspråklighet.

\section{L2-lyssnarnas bedömning av talproven}

I tabell 4 och figur 3 jämförs L2- och L1-lyssnarnas bedömning av talproven. L2-lyssnarna har bedömt talproven på ett likartat sätt som L1-lyssnarna: prov med målspråkliga segment $(4,5,8$ och 9) har fătt högst index, prov med L2-segment lägst index. Prov 5 har fått högst genomsnitt $(5,55)$, vilket ju också gällde L1-lyssnarna $(5,63)$. Målspråksavvikande yttrandeintonation och/eller rytm har inte påverkat L2-lyssnarnas bedömning ifall segmenten har varit målspråkliga (jfr proven 4 och 5 med proven 8 och 9; figur 3). Också bland L2-lyssnarna har dock prov med L2-aktiga segment fått högre index om intonationen och rytmen varit målspråkliga: prov 7 har högre index än proven 2, 3 och 6 (tabell 4). Målspråksavvikelserna i segmenten har bedömts av L2-lyssnarna på samma sätt som av L1-lyssnarna: klusilfelen har störst negativ inverkan på upplevd inföddlikhet följda av vokalerna, supradentalerna och sjeoch tje-ljuden i fallande ordning (tabell 4).

L2-lyssnarna har varit något strängare i sina bedömningar än L1-lyssnarna: detta gäller 11 av proven (tabell 4). L2-lyssnarnas genomsnitt för alla prov är 4,06, medan L1-lyssnarnas genomsnitt är 4,39. Sju av L2-lyssnarna har gett bedömningen 6 för ett eller flera prov; genomsnittligt för 2,8 prov, dvs. för något färre prov än L1-lyssnarna $(3,3)$. L2-lyssnarna har också varit något mer osäkra i sina bedömningar: bara två av nio L2-lyssnare har gett samma bedömning för båda kontrollprov, medan 17 av 30 L1-lyssnare bedömde kontrollproven identiskt.

Tabell 4. L2-lyssnarnas $(n=9)$ och L1-lyssnarnas $(n=30)$ bedömning av talproven. I tabellen anges det genomsnitt som talproven fått av de två lyssnargrupperna. På sista raden anges genomsnittet för alla talprov per lyssnargrupp. 


\begin{tabular}{|l|l|l|}
\hline & L2-lyssn. & L1-lyssn. \\
\hline Prov 1 & 2,77 & 3,4 \\
\hline Prov 2 & 3,22 & 3,3 \\
\hline Prov 3 & 2,37 & 3,3 \\
\hline Prov 4 & 5,12 & 5,6 \\
\hline Prov 5 & 5,55 & 5,63 \\
\hline Prov 6 & 2,88 & 3,26 \\
\hline Prov 7 & 3,66 & 3,66 \\
\hline Prov 8 & 5,22 & 5,46 \\
\hline Prov 9 & 5 & 5,4 \\
\hline Prov 10 & 4,11 & 4,2 \\
\hline Prov 11 & 4 & 3,93 \\
\hline Prov 12 & 4,22 & 4,53 \\
\hline Prov 13 & 4,66 & 5,43 \\
\hline Genomsn. & $\mathbf{4 , 0 6}$ & $\mathbf{4 , 3 9}$ \\
\hline
\end{tabular}

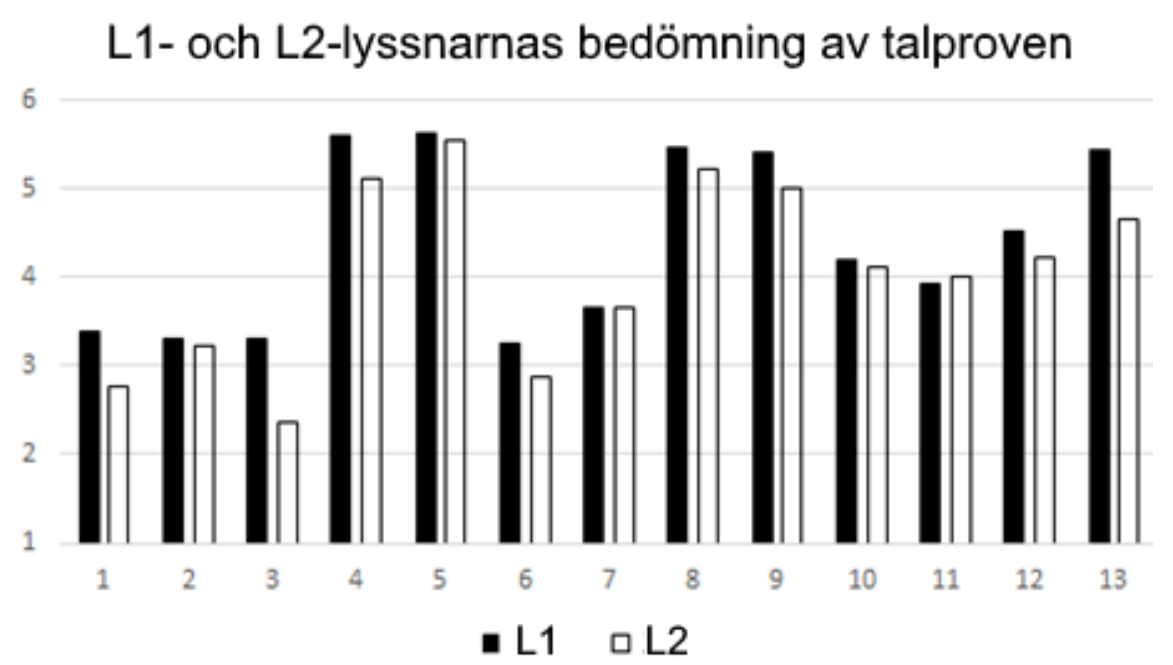

Figur 3. L1-lyssnarnas $(\mathrm{n}=30)$ och L2-lyssnarnas $(\mathrm{n}=9)$ bedömning av talproven. Talproven anges horisontellt (0-13), gruppernas bedömningar vertikalt (1-6). L1-lyssnarnas genomsnitt anges med mörka staplar, L2-lyssnarnas genomsnitt med vita staplar. Elva av talproven har fătt lägre index av L2än av L1-lyssnarna, men generellt har grupperna bedömt proven likartat.

\section{Lyssnarnas kommentarer om talproven}

Lyssnarna har gjort sammantaget 70 kommentarer om talproven. 50 av kommentarerna har gjorts av L1-lyssnarna, och bland dem är det ett tiotal lyssnare som kommenterat proven flitigast; 4-9 kommentarer per lyssnare. Kommentarerna gäller till $70 \%$ segmenten. Lyssnarna har kommenterat mest de prov som hade L2-aktiga segment och som fick lägst index. Av kommentarerna framgår att lyssnarna identifierat talarens L1 som finska i dessa prov. Proven har bl.a. fått följande kommentarer av L1-lyssnarna (semikolon åtskiljer olika lyssnares kommentarer): 
pussen; finsk brytning på p och $b$; ej b; transfer från modersmålet $i p$ och $b$; puss och promsa; u uttalas som o; mycket o i stället för u; hovodet, sjokhos; $u>o$; finsk brytning; bryter på finska; finlandssvenska finsk brytning; mer finskt än finlandssvenska

Prosodin berörs bara i ett fåtal kommentarer, men t.ex. finsk brytning och finlandssvenska kan ju också tolkas syfta på prosodin. Intressant nog är det L2-lyssnarna som tydligare lyfter fram de prosodiska bristerna i prov med lägst index. L2-lyssnarna har kommenterat dessa prov med:

tonen går ned hela tiden; prosodi $i$ Vasagatan; saknar melodi; monoton; brister $i$ melodi och betoning; för mycket förlängning

Båda lyssnargrupper har uppmärksammat de segmentella bristerna också i proven 10-13. Prov 12 med avvikande uttal av supradentaler har kommenterats med rullande $r$; hörs väl på $r$ i fort; hårda $r$ (fort, imorse) respektive rt. Prov 13 (sammanfall av sje och tje) har kommenterats bl.a. med sjukhus sje; sjukhus uttalas norrländskt; kan uppfattas som dialektalt vid t.ex. sch-ljudet respektive hörs brytning t.ex. på sjukhus. Också de prov som fick högst index har kommenterats i ett tiotal fall. Proven 4, 5 och 9 har kommenterats med:

stockholmsdialekt?; stockholmska; rikssvenska (2 ggr); ingen brytning alls; låter som rikssvenska; ingen brytning; extremt lite brytning

I ett fåtal L1-kommentarer nämns dock prosodiska målspråksavvikelser också i proven 5 och 9: intonationen skiljer; betoningen skiljer sig respektive 'körde på' betoning på 'på'. Sammantaget stöder lyssnarnas kommentarer det mönster som återfanns vid bedömningen av talproven: segmentella målspråksavvikelser tycks vara lättare att notera än prosodiska avvikelser, vilket kan förklara att segmenten också påverkat bedömningarna mer. Att prosodin kommenterats mindre än segment kan dock också bero på att lyssnarna saknar ord att påpeka brister i prosodin. Enbart en analys av kommentarerna skulle därför kunna ge en skev bild av vad lyssnarna baserat sina bedömningar på.

\section{Sammanfattande diskussion med kritiska anmärkningar}

Den här undersökningen hade som syfte att analysera olika fonetiska drags betydelse för upplevd inföddlikhet i sverigesvenska. 30 av lyssnarna hade svenska som förstaspråk, 9 lyssnare hade svenska som andraspråk med mycket goda färdigheter i språket. Lyssnarna bedömde uttalets målspråklighet i 13 imiterade talprov på skalan 1-6 (1 = mycket dåligt uttal, mycket kraftig brytning; 6 = inföddlikt). De imiterade talproven varierade enbart fonetiskt, medan innehållet och den manliga talaren var desamma i alla prov.

Resultaten visar att de segmentella målspråksavvikelserna hade störst betydelse för lyssnarnas upplevelse av inföddlikheten (forskningsfråga 1). Ju fler och/eller större segmentella brister talprovet behäftades med, desto lägre index fick det. Målspråksavvikelserna i yttrandeintonation, tonaccenternas realisation och rytm påverkade lyssnarna inte alls i samma utsträckning som de segmentella bristerna. Detta visade sig i att prov med L2-intonation (i 
studien finskpåverkad intonation) och målspråkliga segment fick lika bra bedömning - på gränsen mellan uppfattbar och icke-uppfattbar brytning - som prov med målspråklig intonation och målspråkliga segment. Om segmenten var målspråkliga, fick prov med L2-aktig rytm och målspråklig rytm samma index. Därmed kan rytmen inte sägas vara viktigare än intonationen (forskningsfråga 2), och både rytm och intonation var underordnade segmentkvaliteten. Prov med eller utan tonaccenter fick också en likvärdig bedömning så länge segmenten var målspråkliga (forskningsfråga 3). Av segmentgrupperna hade klusilfel (= oaspirerade /p t k/ och (delvis) avtonade /b d g/) störst negativ inverkan på upplevd inföddlikhet (forskningsfråga 4). Vokalfel och fel i supradentaler påverkade också bedömningarna markant. Bland segmenten hade sammanblandning av sje- och tje-ljuden en mycket liten perceptuell effekt. Lyssnarnas kommentarer till talproven stöder tolkningen att de $\mathrm{i}$ första hand uppmärksammat de segmentella bristerna i proven.

I likhet med tidigare studier (Cunningham-Andersson \& Engstrand, 1988a; Boyd m.fl. 1999) verkade lyssnarna identifiera talarens L1-finska i vissa talprov, men dessa prov beskrevs också som finlandssvenska i några kommentarer. Att klusilfelen hade en stor negativ inverkan på upplevd inföddlikhet ligger i linje med resultaten i Cunningham-Andersson och Engstrands studie (1989a). Yttrandeintonationens och rytmens perceptuella relevans för L1-lyssnarna har oss veterligen inte undersökts tidigare i svenska.

Prosodi antas ofta vara av större betydelse för bra uttal än segment (om svenska se t.ex. Kjellin, 1995 och Bannert, 2004). Resultaten i den här studien bör inte tolkas som att prosodi inte vore viktig för bra uttal - det är inte det resultaten visar, och det är naturligtvis inte heller vår uppfattning. Prosodi - speciellt korrekt ordbetoning och rätt stavelsekvantiteter - är utan tvekan av avgörande betydelse för ordigenkänning och mycket viktigt för ett kommunikativt välfungerande uttal och talets förståelighet. I den här undersökningen hade talproven dock inga grova prosodiska brister (bortsett från prov 1 med fyra felaktiga stavelsekvantiteter), utan proven avvek från målspråket på ett sätt som uppenbarligen i många fall uppfattades av lyssnarna som regional, idiolektisk och/eller situationell variation. Lyssnarnas tolerans t.ex. mot fallande yttrandeintonation kan bero på att liknande intonation förekommer i varianter med relativ tonal jämvikt (dalabergslagsmål, skånska, gotländska och finlandssvenska; Bruce, 2010). Av samma orsak kan lyssnarna vara toleranta mot olika tonala förlopp i satsbetonade ord. Talmodaliteten - uppläst tal - kan också ha påverkat bedömningarna genom att lyssnarna betraktat proven som någonting annat än spontant tal, och därmed varit mer toleranta t.ex. mot fallande eller något monoton intonation. Att segmenten var så viktiga för lyssnarna kan också bero på att segmentella brister är lättare att notera och kategorisera som fel än en avvikelse i rytmen eller yttrandeintonationen. Vidare var talproven relativt korta (21-24 sekunder), och det är möjligt att de prosodiska aspekterna - t.ex. tonaccenterna - hade påverkat bedömningarna mer i längre prov. Med dessa kritiska anmärkningar i åtanke visar resultaten dock att

(i) för ett mycket bra och/eller inföddlikt uttal är målspråkliga segmentkvaliteter av central betydelse,

(ii) lyssnarna verkar tolerera mer prosodiska än segmentella avvikelser vid bedömning av uttalets inföddlikhet och

(iii) åtminstone i uppläst tal tycks segmenten ha ett starkare samband med upplevd inföddlikhet än prosodin. 
Resultaten ger en påminnelse om att segmenten inte ska underskattas vid uttalsundervisning något som riskerar att ske om prosodin ges en alltför dominerande roll på segmentens bekostnad. Vid bedömning av uttal (jfr t.ex. den europeiska referensramen (Council of Europe, 2001) och de allmänna språkexamina i Finland (Allmänna språkexamina, 2016)) anges intonation och satsbetoning som viktiga kriterier på de högsta färdighetsnivåerna, men att segmenten inte nämns där är en brist i ljuset av våra resultat. L2-inlärning av de svenska tonaccenterna har analyserats och diskuterats i ett flertal studier (t.ex. Tronnier \& Zetterholm, 2013 och Kuronen m.fl., 2016). Resultaten här tyder på att det är tveksamt om tonaccenterna ska ställas som inlärningsmål ens på avancerad nivå. Frågan är emellertid komplex, eftersom accentinlärningen tycks främja inlärningen av övriga aspekter av intonation (Kuronen \& Tergujeff, ms.).

Imitationsmetoden tycktes fungera väl. Lyssnarna verkade inte störas av att det var samma talare i varje prov utan de tycktes kunna värdera proven baserat på uttalet, vilket syns i den konsekventa bedömningen och kommentarerna till proven. En omständighet som manar till försiktighet vid tolkning av resultaten är dock att det lexikala innehållet i proven var identiskt. Det kan ha bidragit till att prosodin inte påverkat lyssnarnas bedömningar lika mycket som segmenten och lika mycket som vid spontant tal med varierat lexikalt innehåll. En uppföljande studie med olika innehåll i olika imitationer behövs för att tillförlitligt kunna värdera metoden. Metoden har vidare den svagheten att man inte kan kontrollera varje fonetisk detalj i talproven, och därmed kan man inte heller vara helt säker på att just en viss fonetisk egenskap - och enbart den - påverkat bedömningarna. Om imiterat tal används, bör analysen därför inte inriktas på mycket subtila, svårkontrollerade och svårimiterade fonetiska drag. Enligt vår uppfattning lyckades vi i den här studien analysera sådana fonetiska L2-drag som går att analysera med metoden.

\section{Litteratur}

Abelin, Å. \& Thorén, B. (2015). What affects recognition most - wrong word stress or wrong word accent? Svensson Lundmark, M. et al. (Eds.), Working Papers 55. Proceedings from Fonetik 2015 Lund, June 8-10 2015. Lund: Lund University. 7-10.

Abrahamsson, N. \& Hyltenstam, K. (2004). Mognadsbegränsningar och den kritiska perioden för andraspråksinlärning. Hyltenstam, K. \& Lindberg, I. (Red.), Svenska som andraspråk - i forskning, undervisning och samhälle. Lund: Studentlitteratur. 221-258.

Abrahamsson, N. \& Hyltenstam, K. (2006). Inlärningsålder och uppfattad inföddhet i andraspråket. Lyssnarexperiment med avancerade L2-talare av svenska. Nordand Nordisk tidsskrift for andrespråksforskning, 1:1.9-36.

Abrahamsson, N. (2009). Andraspråksinlärning. Lund: Studentlitteratur.

Allmänna språkexamina. (2016). Bedömningskriterierna för muntlig framställning. https://www.jyu.fi/hum/laitokset/solki/yki/yleista/tietoakielitutkinnoista/puhkriteerit (Tillgänglig 3.12.2016)

Bannert, R. (1984). Problems in learning Swedish pronunciation and in understanding foreign accent. Folia Linguistica, 18, (1-2).193-222. 
Bannert, R. (2004). På väg mot svenskt uttal. Lund: Studentlitteratur.

Bijvoet, E. (1996). Attityder till några varieteter av talad svenska. Thelander, M. m.fl. (Red.), Samspel och variation. Språkliga studier tillägnade Bengt Nordberg på 60-årsdagen. Uppsala universitet: Institutionen för nordiska språk. 55-66.

Boersma, P. \& Weenink, D. (2016). PRAAT: Doing phonetics by computer. [A Computer program]. http://www.fon.hum.uva.nl/praat/. University of Amsterdam, Amsterdam.

Boyd, S., Abelin, Å. \& Dorriots, B. (1999). Attitudes to foreign accents. Andersson, R. et al. (Eds.), Gothenburg Papers in Theoretical Linguistics 81, Proceedings from the Twelfth Swedish Phonetics Conference. Department of Linguistics, University of Gothenburg. 31-35.

Boyd, S. \& Bredänge, G. (2013). Attityder till brytning - exemplet utländska lärare i svenska skolor. Hyltenstam, K. \& Lindberg, I. (Red.), Svenska som andraspråk - i forskning, undervisning och samhälle. Lund: Studentlitteratur. 437-458.

Bruce, G. (1977). Swedish word accents in sentence perspective. (Doktorsavhandling). Lund: LiberLäromedel/Gleerup.

Bruce, G. (2010). Vår fonetiska geografi. Lund: Studentlitteratur.

Bruce, G. (2012). Allmän och svensk prosodi. Lund: Studentlitteratur.

Council of Europe. (2001). Common European framework of reference for languages: Learning, teaching, assessment. Cambridge: Cambridge University Press.

Cunningham-Andersson, U. \& Engstrand, O. (1988a). Which foreign Accents can Swedes identify? Working Papers 34, 1988. Papers from the Second Swedish Phonetics Conference. Lund University: Department of Linguistics.

Cunningham-Andersson, U. \& Engstrand, O. (1988b). Attitudes to immigrant Swedish - a literature review and preparatory experiments. Engstrand, O., Dufberg, M. \& Stark, J. (Eds.), Perilus XIII. Institute of Linguistics, University of Stockholm. 103-152.

Cunningham-Andersson, U. \& Engstrand, O. (1989a). Perceived strength and identity of foreign accent in Swedish. Engstrand, O., Dufberg, M. \& Kylander, C.(Eds.), Perilus X. Experiments in speech processes. Institute of Linguistics, University of Stockholm. 6586.

Cunningham-Andersson, U. \& Engstrand, O. (1989b). Perceived strength and identity of foreign accent in Swedish. Phonetica 46 (4). 138-154.

Dahlbäck, H. (1988). Så tycker man i Malmö om dialekter. Språkvård nr 4, 1988. 10-16.

Derwing, T.M. \& Munro, M.J. (1997). Accent, intelligibility, and comprehensibility. Evidence from four L1s. Studies in Second Language Acquisition, Volume 19, issue 1. Cambridge University Press. 1-16. DOI: https://doi.org/10.1017/s0272263197001010

Derwing, T.M. \& Munro, M.J. (2015). Pronunciation Fundamentals. Evidence-based Perspectives for L2 Teaching and Research. Amsterdam/Philadelphia: John Benjamins Publishing Company.

Flege, J.E. (1984). The detection of French accent by American listeners. Journal of the Acoustical Society of America, 76. 692-707. DOI: https://doi.org/10.1121/1.391256

Fujisaki, H. (1988). A Note on Physiological and Physical basis for the Phrase and the Accent Components in the Voice Fundamental Frequency contour. Fujimura, O. (Ed.), Vocal Physiology: Voice production, Mechanisms, and Functions. New York: Raven Press. 347-355. 
Hahn, L.D. (2004). Primary Stress and Intelligibility: Research to Motivate the Teaching of Suprasegmentals. Tesol Quarterly, Volume 38, Issue 2. 201-223.

Hyltenstam, K. \& Magnusson, E. (1983). Typological markedness, contextual variation, and the acquisition of the voice contrast in stops by first and second language learners of Swedish. Bhatia, T.K. \& Ritchie, W.C. (Eds.), Progression in SLA - Part I. Special Issue of the Indian Journal of Applied Linguistics, IX/1-2. 1-18.

Iivonen, A. (2009). Finnish sentence accent and intonation. de Silva, V. \& Ullakonoja, R. (Eds.), Phonetics of Russian and Finnish: general description of phonetic systems; experimental studies on spontaneous and read aloud speech. Frankfurt am Main: Peter Lang. 67-76.

Jesney, K. (2004). The Use of Global Foreign Accent Rating in Studies of L2 Acquisition. A Report Prepared for the Language Research Centre, University of Calgary.

Kautonen, M. (2016). Finskspråkiga grundskoleelevers uttal av finlandssvenska på olika färdighetsnivåer. Kolu, J. m.fl. (Red.), Svenskan i Finland 16. Jyväskylä Studies in Humanities 298. Jyväskylä: Jyväskylä University. 58-75. https://jyx.jyu.fi/dspace/handle/123456789/52296

Kautonen, M., Kuronen, M. \& Ullakonoja, R. (2016). Studier i uttalsinlärning i finska, svenska och engelska: litteraturöversikt. Puhe ja kieli (Tal och språk), 3. 197-220. https://journal.fi/pk/article/view/59010

Kjellin, O. (1995). Svensk prosodi i praktiken: instruktioner och övningar i svenskt uttal, speciellt språkmelodin. Uppsala: Hallgren \& Fallgren.

Kuronen, M. (2015). Tonaccenterna i avancerade finska inlärares svenska - en akustisk studie. Nordand - Nordisk tidsskrift for andrespråksforskning. Nr.1, 2015. Fagbokforlaget, Bergen. 53-80. https://jyx.jyu.fi/dspace/handle/123456789/46661

Kuronen, M. (2016a). Uttal av S2-finska med fokus på svenskspråkiga talare. Puhe ja kieli (Tal och språk), 3. 147-174. https://journal.fi/pk/article/view/59007

Kuronen, M. (2016b). Avancerade finskspråkiga inlärares uttal av segment i sverigesvenska. Puhe ja kieli (Tal och språk), 3. 175-196. https://journal.fi/pk/article/view/59009

Kuronen, M. \& Leinonen, K. (2010). Svenskt uttal för finskspråkiga. Tampere: Tampereen yliopistopaino.

Kuronen, M. \& Tergujeff, E. (manus). Second Language Prosody and its Development: Interplay between Different Aspects.

Kuronen, M., Ullakonoja, R. \& Kautonen, M. (2016). Inlärningen av de svenska tonaccenterna hos finska S2-talare - automatiseras uttalet? Språk och stil. Vol. 26. Uppsala: Adolf Noreen-sällskapet för svensk språk- och stilforskning. 161-194. http://www.divaportal.org/smash/record.jsf?pid=diva2\%3A1071283\&dswid=330\#sthash.K1PXHeRm.d pbs

Leinonen, A. (2015). "Riittää kun saa selvää": vieraalla aksentilla tuotettu suomi nuorten arvioimana. (Doktorsavhandling). Jyväskylä Studies in Humanities 275. Jyväskylä: Jyväskylä University Printing House. https://jyx.jyu.fi/dspace/handle/123456789/48035

Leinonen, K., Pitkänen, A.J. \& Vihanta, V.V. (1990). Om rytmen i finlandssvenska och sverigesvenska - ett bidrag till forskningen om finlandssvenska. Nikula, K. \& Pitkänen, A.J. (Red.), Svenskan i Finland. Skrifter utgivna av institutionen för filologi II vid Tammerfors universitet. Tammerfors: Tammerfors universitet. 49-100. 
Loman, B. (1973). Miljö och språkförmåga. Svensklärarföreningens årsskrift. 34-60.

Munro, M.J. \& Derwing, T.M. (1995). Foreign accent, comprehensibility, and intelligibility in the speech of second language learners. Language Learning, 45 (1). 73-97. DOI: https://doi.org/10.1111/0023-8333.49.s1.8

Munro, M.J., Derwing, T.M. \& Burgess, C.S. (2003). The detection of foreign accent in backwards speech. Solé, M-J. Recasens, D. \& Romero, J. (Eds.), Proceedings of the $15^{\text {th }}$ International Congress of Phonetic Sciences, Barcelona, Spanien: Universitat Autònoma de Barcelona. 535-538.

Myrberg, S. (2010). The Intonational Phonology of Stockholm Swedish. (Doktorsavhandling). Department of Scandinavian Languages, Stockholm University. http://su.divaportal.org/smash/record.jsf?pid=diva2\%3A312940\&dswid=129

O’Dell, M. (2003). Intrinsic Timing and Quantity in Finnish. Acta Universitatis Tamperensis 979. (Doktorsavhandling). Tampere: University of Tampere. https://tampub.uta.fi/handle/10024/67344

Rasier, L. \& Hiligsmann, P. (2007). Prosodic transfer from L1 to L2. Theoretical and methodological issues. Nouveaux cahiers de linquistique française 28 (2007). Genève: Université de Genève. 41-66.

Riad, T. (2014). The Phonology of Swedish. Oxford: Oxford University Press.

Reuter, M. (1974). Hur härligt sången klingar ... Något om de finlandssvenska språken. Ågren, G. (Red.), Hurrarna, en stridsskrift om finlandssvenskarnas nutid. Vasa: Författarnas andelslag. 30-43.

Toivola, M. (2011). Vieraan aksentin arvioiminen ja mittaaminen Suomessa. (Doktorsavhandling). Helsinki: Unigrafia. http://urn.fi/URN:ISBN:978-952-10-7217-8

Torstensson, N. (2010). Judging the Immigrant: Accents and Attitudes. (Doktorsavhandling). Umeå University: Department of language studies. http://umu.divaportal.org/smash/record.jsf?pid=diva2\%3A282735\&dswid=6149\#sthash.MdWRDJQ1.d $\underline{\mathrm{pbs}}$

Trofimovich, P. \& Baker, W. (2006). Learning Second Language Suprasegmentals: Effect of L2 Experience on Prosody and Fluency Characteristics of L2 Speech. Studies in Second Language Acquisition, 28,1. 1-30. DOI: https://doi.org/10.1017/S0272263106060013

Tronnier, M. \& Zetterholm, E. (2013). Appropriate Tone Accent Production in L2-Swedish by L1-speakers of Somali? Concordia Working Papers in Applied Linguistics, 5, 2014. 722736. https://lup.lub.lu.se/search/publication/cb9e60db-ff83-415a-8c5a-2d042ea4ba4f

Wide, C. (2016). Din svenska, min svenska, vår svenska - om språklig variation i ett jämförande perspektiv. Föredrag vid Svenska litteratursällskapets i Finland årshögtid den 5 februari 2016.

Zetterholm, E. \& Tronnier, M. (2017). Perspektiv på svenskt uttal. Fonologi, brytning och didaktik. Lund: Studentlitteratur. 